\title{
Postmenopozal Dönemde Pilates Egzersizlerinin Yaşam Kalitesi Ve Depresyon Üzerine Etkisi
}

\author{
Özlem Çınar Özdemir®, Muhammet Fatih Uysal®
}

Bolu Abant İzzet Baysal Üniversitesi, Fizik Tedavi ve Rehabilitasyon Yüksekokulu, Bolu, Türkiye

Özlem Çinar Özdemir, Doç. Dr. Muhammet Fatih Uysal, Arş Gör.

Illetişim:

Doç. Dr. Özlem Çınar Özdemir

Bolu Abant İzet Baysal Üniversitesi, Fizik Tedavi ve Rehabilitasyon Yüksekokulu, Bolu, Türkiye Tel: +903742541000

E-Posta: ozlemcinar314@hotmail.com

Gönderilme Tarihi : 14 Şubat 2017

Revizyon Tarihi : : 01 Mart 2017

Kabul Tarihi : : 07 Nisan 2017

\section{ÖZET}

Amaç: Bu çalışma, menopoz sonrası kadınlarda pilates egzersizlerinin yaşam kalitesi ve depresyon üzerine etkisinin incelenmesini amaçladı.

Hastalar ve Yöntemler: Yaş ortalaması 55,71 yıl olan 44 menopoz sonrası dönemdeki kadının, yaşam kaliteleri Menopoza Özgü Yaşam Kalitesi Ölçeği (MÖYKÖ) ile ve depresyon düzeyleri Back Depresyon ölçeği ile değerlendirildi. Bireyler daha sonra pilates egzersizi grubu $(n=21)$ ve ev egzersizi grubu $(n=23)$ olarak 2 'ye ayrıldı. Pilates egzersizi grubuna 8 hafta boyunca haftada 3 gün pilates egzersizleri yaptırılırken, ev egzersizi grubuna ise 8 haftalık ev egzersiz programı verildi. Her iki grup da egzersiz eğitimi öncesi ve 8 hafta sonunda değerlendirildi.

Bulgular: Değerlendirme sonucunda hem MöYKö ölçümlerinde hem de depresyon ölçümlerinde pilates egzersiz grubundaki bireylerin ilk ölçüm ve son ölçümleri arasında istatistiksel olarak anlamlı fark olduğu görüldü $(p<0,05)$.

Sonuç: Bu çalışma ile menopoz sonrası dönemde kadınlara uygulanan pilates egzersizlerinin yaşam kalitelerinde artış sağladığı ve psikolojik durumlarını iyileştirdiği tespit edildi.

Anahtar sözcükler: Menopoz, yaşam kalitesi, egzersiz, depresyon

\section{THE EFFECT OF PILATES EXERCISE ON QUALITY OF LIFE AND DEPRESSION IN POSTMENOPAUSAL PERIOD}

\section{ABSTRACT}

Objectives: This study aimed to investigate the effect of pilates exercises on quality of life and depression in postmenopausal women.

Patients and Methods: The postmenopausal women with a mean age of 55.71 years were assessed with their Quality of Life Menopause Specific Quality of Life Scale (MENQOL) and their depression levels by the Back Depression Scale. The individuals were later divided into two groups as the pilates exercise group ( $n=21$ ) and the home exercise group $(n=23)$. The Pilates exercise group had 3 days a week of pilates exercises for 8 weeks, while the home exercise group had an 8-week home exercise program. Both groups were evaluated pre-exercise and at the end of 8 weeks.

Results: As a result of the evaluation, it was observed that there was a statistically significant difference between the first and last measurements of the individuals in the Pilates exercise group in both the MENQOL measures and the depression measures $(p<0.05)$.

Conclusion: This study showed that pilates exercises applied to women in the postmenopausal period increased the quality of life and improved their psychological conditions.

Keywords: Menopause, quality of life, exercise, depression 
$\mathbf{M}$ enopoz menstrüel döngünün kesildiği ve bunun sucunda ovaryan hormonlar olan östrojen ve progesteronun salınımındaki azalmayı tarif eden yaşam dönemine verilen isimdir (1). Artan yaşam süresi ile birlikte kadınlar artık menopoz sonrası döneminde daha fazla zaman geçirmektedir (2).

Menstrüel sonlanma yaşı farklı ülkelere göre geniş bir dağılım göstermektedir. İtalya, İran, Slovenya ve ABD'de 50-51 yaş olarak öngörülen son menstrüel kanama, Kore, Lübnan, Singapur, Yunanistan, Fas, Meksika, Tayvan ve ülkemizde 47-50 yaş olarak bildirilmiştir $(3,4)$.

Menopoza geçiş süreci genellikle yaşlanma ve sosyal uyumun da beraberinde getirdiği etkiler eşliğinde tanımlamaya çalıştığımızda ortaya biyolojik, psikolojik ve sosyal faktörlerin dahil olduğu karmaşık bir fizyolojik bir süreç ortaya çıkar $(5,6)$. Menopoz dönemi boyunca bazı kadınlarda belirgin değişiklikler ortaya çıkarken bazı kadınlarda daha hafif değişiklikler görülebilir (7). Menopoz kadınların vücutlarında vazomotor, uyku bozuklukları, yorgunluk, ağrı ve sızılar, değişmiş bilişsel işlevlerin yanı sıra vajinal kuruluk, tahriş, tekrarlayan idrar yolu enfeksiyonları, pelvik iç organları destekleyen bağ dokusundaki zayıflama gibi genitoüriner sorunlar şeklinde birçok değişimler meydana getirmektedir. Uzun dönemde ise kas iskelet sisteminde kaçınılmaz değişiklikler yaşanmaktadır. Osteoporoz, sarkopeni, postüral disfonksiyon, yürüyüş döngüsünde gerileme, denge kontrolü ve stabilitede kayıp ile birlikte artan düşme riski bu dönemde bildirilen değişimlerdir (8). Belirtilen bu etkiler, kadınların yaşam kalitesini olumsuz yönde etkilemektedir (9).

Menopoz döneminde vurgulanan değişimlerden biri ise menopoz öncesi, menopoz başlangıcı ve menopoz sonrası dönemlerde birbirinden bağımsız şekilde yüksek seviyeli depresif semptom görülme riskinde artıştır (10). Bu nedenle üretken dönemden menopoz dönemine geçiş depresyona yatkınlık riskini arttıır ve bu durumu önlemek için özellikle ilaç dışı müdahalelerin kullanılmasının daha faydalı olduğu bildirilmiştir (11).

Fiziksel egzersiz, yağ kütlesini ve obeziteyi azaltarak yaşam kalitesini arttırmada ve kas liflerinin büyüklüğü ve sayısında hızıı bir azalmayı önlemede etkilidir $(12,13)$. Kadınların orta yaş döneminden itibaren orta şiddetli egzersiz yapmalarının sağlık risklerinde azalma sağladığı bildirilmiştir (14). Amerikan Spor Hekimliği Koleji (ASHK) orta yaş sonrasında kullanılan egzersiz eğitimlerinde; direnç, güç, aerobik kapasite, esneklik egzersizlerine odaklanır ve buna yönelik egzersizleri bir rehber olarak önermektedir (15). Bu içeriğin bir parçası olarak 'Pilates Yöntemi' üzerinde durulmuştur ve beyin hücrelerinin aktivasyonu yoluyla, aklın uyarılmasını ve bu durumun vücut üzerinde olumlu etkisinin olduğundan bahsetmiştir (16).

Popüler bir egzersiz programı olan pilates ismini metodun kurucusu olan Joseph Pilates'ten almıştır ve 1920 'lerde geliştirilmeye başlanmıştır. Düşük şiddetli olan bir seri egzersizden oluşmaktadır ve tüm vücutta esneklik ve kuvvet artışı sağladığı düşünülmektedir. Pilates egzersiz metodunu destekleyenler, bu egzersizlerin tüm vücutta zihin-beden bağlantısını iyileştirdiğini savunurlar. Pilates eğitmenleri birtakım sözel işaretlerle bu teknikleri öğretir ve özellikle "kor" bölgesi olan abdominal, alt sırt ve pelvik yapıyı döşeyen kasları vurgular. Egzersizde vücudu bir yay gibi kullanarak ağırlığının bir şekilde direnç olarak kullanılmasını içerir (16).

Bu çalışmada amacımız menopoz sonrası dönem kadınlarda, pilates eğitimi ve ev egzersiz eğitiminin yaşam kalitesi ve depresyon parametreleri üzerine etkisini incelemektir.

\section{Hastalar ve yöntemler}

Bu çalışmaya Bahçelievler Sağlık Ocağı ve Bolu Yaşı Sağlığı Merkezi (BOVYAM) bünyesinde kayıtlı aile hekimi tarafından menopoz tanısı alan 44 birey dahil edildi.

Bu çalışma, Klinik Araştırmalar Etik Kurulu'nda değerlendirilmiş olup, etik açıdan uygun bulunmuştur (Protokol No. 2014/18). Çalışmaya katılan bireylere öncelikle standart bir seminer programı düzenlendi. Bu seminerde çalışma hakkında bilgi verildi, çalışmanın amacı, hedefleri, süresi, yapılacak uygulamaların şekli, kullanılacak değerlendirme yöntemleri, yazılı, görsel ve sözlü olarak anlatıldı.

Çalışmaya dahil edilme kriterleri egzersiz yapmaya uygun fiziksel veya algısal yeterlilikte olma, omurgaya ait herhangi bir patolojisi ya da deformitesi olmama, çalışmaya katılmak için gönüllü olma, en az 12 aydır adet görememe ve hormonal olarak, cerrahi sebepli veya doğal menopozun doğrulandığı kadınlar olarak belirlendi. Ciddi kalp hastalığı (aort stenozu, anjina, hipertrofik kardiak myopati, aritmi, kalp pili) olanlar, inflamatuar veya sistemik hastalığı olanlar, malignensi, psikolojik fonksiyon bozukluğu, kortikosteroid kullanımı olanalar ve kemik yoğunluğu ölçüm sonuçları (DEXA)'na göre T skoru'-2,5' altında olan kadınlar çalışma dışı bırakıldı. 
Çalışmaya dahil edilmesi uygun olan 44 birey, 2 gruba ayrıldı. Tüm bireyler değerlendirildikten sonra egzersiz programına alındı. Illk gruba Pilates egzersizlerinden oluşan program pilates eğitimi almış fizyoterapist tarafından uygulandı. Íkinci gruba ise korseleme ve solunum tekniklerinin dahil edilmediği aynı egzersizler ev programı şeklinde uygulandı. Her iki grupta da egzersiz programları ısınma ve soğuma periyotlarından oluştu ve haftada 3 gün, günde 1 saat, 8 hafta boyunca sürdü.

Çalışmaya dahil edilmesi uygun olan bireyler, egzersiz eğitimi öncesi ve sonrası olmak üzere toplam iki kez değerlendirildiler. Değerlendirmede ad, soyad, telefon, medeni hal, çalışma durumu, sigara kullanımı gibi kişisel bilgileri, yaş, obstetrik hikaye, kadın hastalığı olma durumu, tıbbi özgeçmiş, kullanılan ilaçlar, öğrenim durumu, ağrı durumu gibi demografik ve klinik bilgileri içeren bilgi formu, yaşam kalitesi ve depresyon anketleri kullanıldı.

Menopoz sonrası kadınların yaşam kalitelerini değerlendirmede menopoza özgü yaşam kalitesi ölçeği (MÖYKÖ) kullanıldı. MÖYKÖ, John R. Hilditch, Jacqueline Lewis ve arkadaşları tarafından 1996 yılında, kadınların deneyimlerine dayalı psikometrik özelliklerle, menopozda sağlık durumuna özgü bir yaşam kalitesi ölçeği oluşturmak amacıyla geliştirilmiştir. 2005 yılında Doç. Dr. Nevin H. Şahin tarafından Türk toplumuna uyarlanıp geçerlilik ve güvenilirliği yapılmıştır (17).

MÖYKÖ 29 soru içeren likert tipte bir ölçektir. Vazomotor, psikososyal, fiziksel ve cinsel olmak üzere 4 alt alandan oluşur. MÖYKÖ'de her bir alt alan puanı 1'den 8'e doğru sıralanmıştır. 1 puan o konuyla ilgili herhangi bir sorun yaşanmadığını gösterir. 2 puan o konunun var olduğunu, yaşandığını ancak hiç rahatsız edici olmadığını işaret eder 3-8 arasındaki puanlar ise var olan sorunun şiddetini ve artan derecelerini gösterirler.

Beck Depresyon Ölçeği (BDÖ), Beck ve arkadaşları tarafından depresyonun davranışsal bulgularını ölçmek amacı ile 1961 yılında geliştirilmiştir. BDÖ formunda 21 kategori ve her bir kategori için dört madde vardır. Bireyden uygulama günü de dahil son bir hafta içinde kendisini nasıl hissettiğini en iyi ifade eden maddeyi seçerek işaretlemesi istenir. Her madde 0 ile 3 arasında puan alır alınabilecek en yüksek puan $63^{\prime}$ tür. Toplam puanın yüksek oluşu depresyon düzeyinin ya da şiddetinin yüksek oluşunu belirtir. BDÖ'nün ülkemizde geçerlilik ve güvenirlik çalışmasını Hisli ve ark tarafından yapılmıştır (18).
Pilates egzersiz eğitimi grubu

Pilates egzersiz grubunda olan bireylere pilates öncelikle stabilizasyon kavramının anlatılığı 1 saatlik teorik eğitim ile başlandı. Stabilizer ile abdominal kor bölgesi kontrolünün nasıl yapılacağı ve klinik pilates egzersizlerinin ana prensipleri olan beş anahtar element öğretildi. Eğitimle boyun, omuz, lumbopelvik bölge, göğüs kafesi, duruş özellikleri ve yapılan egzersiz sırasında bu duruş özelliklerini korurken aynı zamanda solunum kontrol etmesi istendi. Egzersiz eğitimi on kişilik gruplar halinde verildi. Her egzersiz hareketi 10 tekrar ile tamamlandıktan sonra diğer harekete geçildi. Egzersiz programının 30. dakikasında nefes egzersizleri yapılarak aktif dinlenme sağlandı. Egzersiz programı 1 saat süresince devam etti.

Isınma ve soğuma periyodunda yavaş yürüme, hızlı yürüme, yavaş ve tempolu koşu egzersizleri, mini skuat (çömelme), , roll down (aşağı yuvarlanma), toy soldier (oyuncak asker), kleopatra, chest stretch (göğüs germe), swinging (sallanma) egzersizleri uygulandı. Ardından hundreds (yüzler), one leg strech (tek bacak germe), double leg strech (çift bacak germe), shoulder bridge (köprü), hip twist (kalça döndürme), one leg kick (tek bacak tekme), swimming (yüzme), clam (istiridye), side kick (yan tekme), half roll back (yarım geri yuvarlanma), one leg sircle (tek bacak daire çizme), breast stroke (kurbağalama yüzme) ve kobra hareketleri yapıldı.

\section{Ev egzersiz eğitimi grubu}

Ev egzersiz grubuna ise yapılacak egzersizler sırasında dikkat edilmesi gereken prensipler hakkında bir sunum yapıldı. Uygulanması istenen egzersizler teker teker gösterildi. Illk 4 hafta boyunca elastik bant kullanılmadan egzersizlerin yapılması, son 4 haftada ise egzersiz programına elastik bant eklenerek egzersizleri yapmaları istendi. Ardından egzersizlerin bulunduğu broşür bireylere teslim edildi. 8 hafta boyunca haftada 3 gün her seferinde 1 saat boyunca 10 tekrarlı olarak verilen broşürdeki hareketleri yapmaları istendi. Broşürün arkasında hazırlanmış olan egzersiz takip cetvellerini nasıl dolduracakları anlatıldı.

Elde edilen ölçümlere ait tanımlayıc değerler ortalama, ortanca değer, standart sapma, sayı ve \%frekanslar olarak hesaplanmış ve tablolar halinde verildi. Sayısal özelliklerin her bir grupta normal dağılım gösterip göstermediği Kolmogorov-Smirnov testi ile incelenmiştir. İki grubun karşılaştırılmasında parametrik olmayan Mann-Whitney $U$ testi kullanıldı. Ayrıca her bir grupta ayrı ayrı egzersiz öncesi ve egzersiz sonrası arasındaki farkların anlamlı olup olmadığı Wilcoxon Sign Rank testi ile değerlendirildi. İstatistik anlamlılık düzeyi $\mathrm{P} \leq 0,05$ alınmış ve hesaplamalarda PASW (ver. 18) programı kullanıldı. 


\section{Bulgular}

Çalışmaya BOVYAM ve Bahçelievler sağlık ocağına kayıtlı olan ve aile hekimi tarafından egzersiz yapmaları amacı ile yönlendirilen menopoz sonrası yaş ortalamaları 1. grupta $57,38( \pm 6,1), 2$. grupta $54,04( \pm 5,9)$ olan 44 birey dahil edildi. Çalışmada yer alan 44 birey 2 gruba ayrıldı. 1. gruba pilates egzersizleri, 2 . gruba ev egzersiz programı verildi. Bireylerin tümü seansların hepsine katılarak çalışmayı tamamladılar. Bireylerin yaş (yıl), boy $(\mathrm{cm})$, kilo $(\mathrm{kg})$, Vücut kütle indeksi (VKi) $\left(\mathrm{kg} / \mathrm{m}^{2}\right)$ değerleri guruplar arası kıyaslandığında tedavi öncesi tedavi öncesi sayılan fiziksel özellikler açısından benzer oldukları görüldü $(p>0,05)$ (Tablo 1).

Bireylerin tanımlayıcı özelliklerinden eğitim durumu, meslek bilgileri ve medeni durumları ile ilgili bilgilerin gruplara göre dağılımı sayı (n) ve yüzde (\%) olarak Tablo 2'de gösterildi.

Tablo 1. Bireylerin fiziksel özelliklerinin gruplar arası karşılaştırımas

\begin{tabular}{lccccc} 
Fiziksel Özellikleri & Grup & $\boldsymbol{n}$ & $\boldsymbol{X}$ & SS & $\boldsymbol{p}$ \\
\hline \multirow{2}{*}{ Yaş (yıl) } & 1. Grup & 21 & 57,38 & 6,10 & 0,055 \\
& 2. Grup & 23 & 54,04 & 5,97 & \\
\multirow{2}{*}{ Boy uzunluğu (cm) } & 1. Grup & 21 & 160,62 & 6,17 & 0,253 \\
& 2. Grup & 23 & 158,70 & 5,98 & \\
Vücut ağırlığı (kg) & 1. Grup & 21 & 77,24 & 12,10 & \multirow{2}{*}{0,664} \\
& 2. Grup & 23 & 75,88 & 13,07 & \\
VKi (kg/m²) & 1. Grup & 21 & 30,10 & 4,22 & \multirow{2}{*}{0,481} \\
& 2. Grup & 23 & 29,60 & 4,95 & \\
\hline
\end{tabular}

X: Ortalama, SS: Standart sapma, $\mathbf{p}<0,05$.

Tablo 2. Bireylerin tanımlayıcı özelliklerinin gruplara göre dağılımı

\begin{tabular}{lcccc}
$\begin{array}{l}\text { Tanımlayıcı } \\
\text { Özellikler }\end{array}$ & \multicolumn{2}{c}{$\begin{array}{c}\text { Pilates Egzersizi } \\
\text { Grubu }\end{array}$} & \multicolumn{2}{c}{$\begin{array}{c}\text { Ev Egzersizi } \\
\text { Grubu }\end{array}$} \\
\hline & $n$ & $\%$ & $n$ & $\%$ \\
\hline Medeni durum & & & & \\
Evli & 16 & 76,2 & 20 & 87,0 \\
Bekâr & 5 & 23,8 & 3 & 13,0 \\
Eğitim Durumu & & & & \\
Ilkokul mezunu & 6 & 28,6 & 7 & 30,4 \\
Ortaokul mezunu & 2 & 9,5 & 3 & 13,0 \\
Lise mezunu & 5 & 23,8 & 9 & 39,1 \\
Üniversite mezunu & 8 & 38,1 & 4 & 17,4 \\
Çalışma durumu & & & & \\
Ev Hanımı & 6 & 28,6 & 12 & 52,2 \\
Çalışıyor & 2 & 9,5 & 3 & 13,0 \\
Emekli & 13 & 61,9 & 8 & 34,8
\end{tabular}

Bireylerin sağlıkla ilgili tanımlayıcı özelliklerinin gruplara göre dağııımı sayı (n) ve yüzde (\%) olarak tablo 3'de gösterildi. Tablo incelendiğinde sigara kullanım sıklığı, var olan kadın hastalık tiplerinin dağılımı, kadın hastalığı nedeniyle operasyon geçirenlerin sıklığı, kronik hastalıkların dağılımı, kullanılan ilaçların dağılımı, idrar kaçırma sıklığı, menopoza girme şekli, düzenli doktor kontrolü olanların sıklığı ve Hormon Replasman Tedavi olanların sıklığı her iki grupta da benzer oranda bulundu $(p>0,05)$.

Tablo 3. Bireylerin sağlıkla ilgili tanımlayıcı özelliklerinin gruplara göre dağılımı

\begin{tabular}{|c|c|c|c|c|c|c|}
\hline & \multicolumn{2}{|c|}{$\begin{array}{c}\text { Pilates Egzersizi } \\
\text { Grubu }\end{array}$} & \multicolumn{2}{|c|}{$\begin{array}{c}\text { Ev Egzersizi } \\
\text { Grubu }\end{array}$} & \multirow[t]{2}{*}{$p$} \\
\hline & & $n$ & $\%$ & $n$ & $\%$ & \\
\hline \multirow{2}{*}{ Sigara kullanımı } & Hayır & 13 & 61,9 & 14 & 60,9 & \multirow{2}{*}{0,94} \\
\hline & Evet & 8 & 38,1 & 9 & 39,1 & \\
\hline \multirow{2}{*}{ Kadın Hastalığı } & Yok & 16 & 76,2 & 15 & 65,2 & \multirow{2}{*}{0,80} \\
\hline & Var & 5 & 23,8 & 8 & 34,8 & \\
\hline \multirow{3}{*}{$\begin{array}{l}\text { Kadın Hastalığı } \\
\text { Nedeniyle Geçirilmiş } \\
\text { Operasyon }\end{array}$} & Hayır & 19 & 90,5 & 17 & 73,9 & \multirow{3}{*}{0,15} \\
\hline & & & & & & \\
\hline & Evet & 2 & 9,5 & 6 & 26,1 & \\
\hline \multirow{2}{*}{ Kronik Hastalık } & Yok & 4 & 19,0 & 6 & 26,1 & \multirow{2}{*}{0,96} \\
\hline & Var & 17 & 81,0 & 17 & 73,9 & \\
\hline \multirow{2}{*}{$\begin{array}{l}\text { Düzenli İlaç } \\
\text { Kullanılanımı }\end{array}$} & Yok & 5 & 23,8 & 7 & 30,4 & \multirow{2}{*}{0,951} \\
\hline & Var & 16 & 76,2 & 16 & 69,6 & \\
\hline \multirow{2}{*}{ İdrar Kaçırma } & Yok & 14 & 66,7 & 10 & 43,5 & \multirow{2}{*}{0,12} \\
\hline & İdrar kaçırıyor & 7 & 33,3 & 13 & 56,5 & \\
\hline \multirow{2}{*}{$\begin{array}{l}\text { Menopoza } \\
\text { Girme Şekli }\end{array}$} & Doğal & 18 & 85,7 & 19 & 82,6 & \multirow{2}{*}{0,77} \\
\hline & Cerrahi sonrası & 3 & 14,3 & 4 & 17,4 & \\
\hline \multirow{2}{*}{$\begin{array}{l}\text { Düzenli Doktor } \\
\text { Kontrolü }\end{array}$} & Evet & 8 & 38,1 & 6 & 26,1 & \multirow{2}{*}{0,393} \\
\hline & Hayır & 13 & 61,9 & 17 & 73,9 & \\
\hline \multirow{2}{*}{$\begin{array}{l}\text { Hormon Replasman } \\
\text { Tedavisi }\end{array}$} & Yok & 17 & 81,0 & 19 & 82,6 & \multirow{2}{*}{0,887} \\
\hline & Var & 4 & 19,0 & 4 & 17,4 & \\
\hline
\end{tabular}

Bireylerin ilk ölçüm ve son ölçüm menopoza özgü yaşam kalitesindeki değişiklikler değerlendirildi. Değerlendirme sonucunda hem MÖYKÖ ölçümlerinde pilates egzersiz grubundaki bireylerin ilk ölçüm ve son ölçümleri arasında istatistiksel olarak anlamlı fark olduğu görüldü $(p<0,05)$ (Tablo 4).

Bireylerin ilk ölçüm ve son ölçüm depresyon düzeyleri incelendiğinde pilates egzersiz grubu lehine istatiksel olarak anlamlı fark saptandı $(\mathrm{p}<0,05)$ (Tablo 5). 
Tablo 4. Bireylerin MÖYKÖ değerlerinin ilk ve son ölçüm değerlendirme sonuçları

\begin{tabular}{|c|c|c|c|c|}
\hline & & $\begin{array}{c}\text { İk Ölçüm } \\
X \pm \text { SS }\end{array}$ & $\begin{array}{c}\text { Son Ölçüm } \\
X \pm S S\end{array}$ & $p$ \\
\hline \multirow{2}{*}{ MÖYKÖ } & $\begin{array}{l}\text { Pilates Egzersizi Grubu } \\
(\mathrm{n}=21)\end{array}$ & $51,52 \pm 20,87$ & $35,35 \pm 17,16$ & $0,001^{*}$ \\
\hline & $\begin{array}{l}\text { Ev Egzersizi Grubu } \\
(n=23)\end{array}$ & $58,61 \pm 32,23$ & $56,87 \pm 32,01$ & 0,474 \\
\hline
\end{tabular}

$\mathrm{P}<0,05$, Wilcoxon Rank Test, MöYKÖ: Menopoza Özgü Yaşam Kalitesi Ölçeği.

Tablo 5. Bireylerin ilk ölçüm ve son ölçüm depresyon değerlendirme sonuçları

\begin{tabular}{lccc} 
Beck Depresyon Ölçeği & $\begin{array}{c}\text { Ilk Ölçüm } \\
X \pm \text { SS }\end{array}$ & $\begin{array}{c}\text { Son Ölçüm } \\
X \pm S S\end{array}$ & $\boldsymbol{P}$ \\
\hline Pilates Egzersizi Grubu $(\mathbf{n = 2 1 )}$ & $6,05 \pm 3,55$ & $4,24 \pm 2,87$ & $\mathbf{0 , 0 0 3}^{*}$ \\
Ev Egzersizi Grubu $(\mathbf{n}=\mathbf{2 3})$ & $5,91 \pm 3,31$ & $5,35 \pm 3,17$ & 0,300 \\
\hline$p<0,05$ Wilcoxon Rank Test. & & &
\end{tabular}

Bireylerin genel ve menopoza özgü yaşam kalite ve depresyon ölçüm farkları gruplar arası karşılaştıııldığında yaşam kalitesi ve depresyon düzeylerinde istatistiksel olarak anlamlı fark olduğu bulundu $(p<0,05)$ (Tablo 6).

\begin{tabular}{|c|c|c|c|c|}
\hline & & $X \pm S S$ & Median & $p$ \\
\hline \multirow{2}{*}{ MÖYKÖ } & $\begin{array}{l}\text { Stabilizasyon Egzersizi Grubu } \\
(\mathrm{n}=21)\end{array}$ & $17,10 \pm 14,93$ & 20,00 & \multirow{2}{*}{$0,011^{*}$} \\
\hline & $\begin{array}{l}\text { Ev Egzersizi Grubu } \\
(\mathrm{n}=23)\end{array}$ & $1,73 \pm 20,69$ & 2,00 & \\
\hline \multirow{2}{*}{ BDÖ } & $\begin{array}{l}\text { Stabilizasyon Egzersizi Grubu } \\
(\mathrm{n}=21)\end{array}$ & $1,80 \pm 2,15$ & 2,00 & \multirow{2}{*}{$0,032^{*}$} \\
\hline & $\begin{array}{l}\text { Ev Egzersizi Grubu } \\
(\mathrm{n}=23)\end{array}$ & $0,56 \pm 2,51$ & 1,00 & \\
\hline
\end{tabular}

p<0,05 Man Whitney U test, MöYKö: Menopoza Özgü Yaşam Kalitesi Ölçeği, BDÖ: Beck Depresyon Ölçeği

\section{Tartışma}

Bu çalışma ile postmenopozal kadınlarda pilates egzersizlerinin yaşam kalitesini arttırarak depresyon düzeylerini azalttığı gösterildi.

Menopoz semptomlarını değerlendirmek için birçok yöntem geliştirilmiştir ancak bunlardan küçük bir kısmı standardize, geçerli ve güvenilirdir. "Green Klimakterik Ölçeği", "Kupperman İndeksi", "MÖYKÖ" güncel olarak kullanılan ölçüm yöntemlerindendir (1). Çalışmamızda postmenopozal dönemdeki bireylerin yaşam kaliteleri MÖYKÖ ile değerlendirildi.
Kim ve ark. 631 perimenopozal kadın üzerindeki çalışmalarında MÖYKÖ ve uluslararası fiziksel aktivite anketi ile değerlendirme yapmışlardır. Yüksek fiziksel aktivite düzeyinin MÖYKÖ total ve alt skorlarını etkilemediği, ancak orta şiddette fiziksel aktivitenin psikososyal ve fiziksel semptomlarda azalma sağladığı bildirilmiştir. Sonuç olarak orta şiddetli fiziksel aktivitenin perimenopozal kadınlarda psikososyal ve fiziksel menopoz semptomlarını azalttığı belirtilmiştir (19). 2606 kadının dahil edildiği benzer bir çalışmada ise fiziksel aktivite şiddeti ile MÖYKÖ arasındaki ilişki değerlendirilmiştir. Fiziksel inaktif olan kadınlar, aktif kadınlar ile kıyaslandığında; kaygı depresyon düzeylerinde artış, iyilik halinde azalma, hafıza konsantrasyon problemleri, yaşadıkları bildirilmiştir. Aynı zamanda fiziksel olarak aktif kadınların daha iyi bir yaşam kaliteleri olduğu bildirilmiştir (20).

Literatürde postmenopozal bireylerde pilates egzersizleri kullanılarak yaşam kalitesini inceleyen az sayıda çalışma mevcuttur (21-24). Küçükçakır ve ark. postmenopozal kadınları pilates egzersiz grubu $(n=30)$ ve ev egzersizi grubu $(n=30)$ olarak iki gruba ayrılmışlardır. Çalışmayı 1 yıl boyunca haftada 2 kez 1'er saat uygulamışlardır. Kadınların ağrı, yaşam kalitesi değerleri incelenmiştir. Tüm parametrelerde pilates grubunun ev egzersizi grubuna üstünlüğü bildirilmiştir. Çalışmalarının sonucunda pilates egzersizlerinin ağrı, fonksiyonel kapasite ve yaşam kalitesi üzerine postmenopozal kadınlarda olumlu etki gösterdiği bildirilmiştir (22). Rodríguez-Fuentes ve ark. çalışmalarında 12 hafta boyunca haftada 2 kez 60 dakikalık pilates egzersizleri uyguladıkları kadınlarda yaşam kalitelerinde egzersiz sonrası önemli gelişme bildirmişlerdir (24). Birçok çalışmada pilates egzersiz metodu kullanılarak postmenopozal dönemi kadınlarda yaşam kalitesinin arttığı bildirilmiştir $(23,25,26)$. Bu çalışmada bireylerin gruplar arası yaşam kaliteleri ölçümleri karşılaştırıldığında, MÖYKÖ değerlerinde pilates egzersizi grubu lehine anlamlı bir fark olduğu görüldü. Sonuçlarımız grup şeklinde uygulanan pilates egzersizlerinin postmenopozal dönemdeki bireylerde yaşam kalitesini önemli ölçüde arttırdığını gösterdi.

Fiziksel aktivitenin veya farklı türde egzersizlerin yaşam kalitesini olumlu yönde etkilediği bilinmektedir (24). Antunes ve ark. aerobik egzersiz programı uyguladıkları bireylerin egzersiz sonrası yaşam kalitesinde anlamlı gelişme sağladığını belirtmişlerdir. Bir başka çalışmada bir grup postmenopozal dönemdeki kadınlara haftada 3 kez, 12 ay boyunca egzersiz programı uygulanmış ve sedanter kontrol grubu ile karşılaştırıldığında genel yasam kalitelerinde anlamlı fark olduğu bildirilmiştir (27). Villaverde-Gutierrez ve ark. yaptıkları çalışmada ise bir grup menopoz kadına haftada 3 saat egzersiz 12 ay boyunca uygulanmış ve bu grup sedanter kontrol grubu ile kıyaslandığında egzersiz 
grubu lehine fiziksel ve mental sağlıkları ile genel yaşam kalitelerinde istatistiksel anlamlı fark belirtilmiştir (28). Çalışmamızda ev egzersiz grubunda 8 hafta sonunda yaşam kaliteleri açısından çok az bir değişim olduğu gözlendi. Bu grupta yer alan bireylerin düzenli egzersiz yapma bilincini tam olarak yerleştirememelerinden dolayı egzersizlerin yaşam kalitelerinde olumlu etki yaratacak düzeyde bir gelişim oluşturmadığını düşünmekteyiz.

İnsanın gelişim sürecinde çözmesi ve uyum sağlaması gereken yaşam dönemlerinin her birinin kendine özgü stres oluşturucu değişimleri vardır. Kadın için menopoz, bu yaşam dönemlerinden bir tanesidir. Menopoz döneminde ortaya çıkan ruhsal belirtilerin nedeni açıcça belirtilmese de hormonal değişimlerin doğrudan etkisi olabileceği, fiziksel belirtilere ikincil olabileceği ya da psikososyal etkiyle ortaya çıkabileceği, hatta beden imajındaki değişikliklerin ve artan uyku bozukluğunun depresyon gelişmesinde rol oynayabileceği ileri sürülmektedir (29). Bayanlarda majör depresif bozukluk gelişme riskinin erkeklere oranla 1,7 kat daha fazla olduğu bilinmektedir. Yapılan çok merkezli, çok kültürlü, toplum temelli kohort çalışmasında, menopozal durumun erken ya da geç olmasının depresyon semptomlarındaki artış riski ile ilişkisinin birbirinden bağımsız olduğu gösterilmiştir. Menopozal geçiş döneminde gösterilen bu depresyon sorununu önleme ve müdahale etmekte özellikle ilaç dışı yaklaşımlardan yararlanılması gerekliliği belirtilmiştir (11).

Egzersizin düşük maliyetli ve az riskli, ayrıca fiziksel sağlık açısından sürdürülebilir etkisi olmasına karşın, özellikle kadınlarda yaygın görülen depresyon semptomlarını azaltmada henüz ilk basamak tedavi seçeneği olarak dikkate alınmamaktadır. Egzersizin fizyolojik ve psikolojik mekanizmaların inflamasyonunu azalttığı, nörotransmitter seviyesinin özellikle dopamin ve seratonin seviyesini arttırarak beyin aminerjik sinaptik geçişini arttırdığı, endorfin sekresyonunu çoğalttığı, stresli uyarıların dağılmasını sağladığı ayrıca öz-yeterlik ile benlik saygısını geliştirdiği bunun da koruyucu etki oluşturduğu bildirilmiştir. Çalışmalar 12 haftalık egzersiz programının menopoz dönemindeki kadınlarda depresyon semptomlarını azaltıCı etkisi olduğunu göstermektedir (30). Bir çalışmada, 12 haftalık egzersiz öncesi ve sonrasında pro-imflamatuar sitokinler ölçülmüştür ve depresyon semptomlarında yüksek azaltıcı etkiyle ilişkilendirilen tümör nekroz faktör alfa seviyesinde artış bulunmuştur (30). Endojenöz opioidler gibi endokanabinoidler, kaygı giderici ve ağrı kesici olarak bilinirler ve egzersiz sonrasında vücut konsantrasyonunda bunların artışı gösterilmiştir. Bu durum fiziksel aktivitenin ruh sağlığı üzerine olan etkisinin fizyolojik temelli akılcı bir mekanizması olarak kabul edilebilir. Egzersizin birçok nörotropik faktörü arttırdığı hayvan ve insan deneyleriyle gösterilmiştir ve bu durumun prefrontal kortekste antidepresan ilaçların etkisi ile paralel bir etkiye sebep olduğu nörolojik görüntüleme ile desteklenmiştir $(11,31)$.

Çalışmalar fiziksel egzersiz eğitiminin depresif semptomlar ve anksiyetede iyileşme sağladığını bildirmektedir. Dugan ve ark. 42-52 yaş aralığındaki kadınlarla yaptığı çalışmalarda fiziksel aktivite şiddeti arttıkça depresif semptomlarda zamanla azalma geçekleştiğini belirtmiştir (11). Mokhtaria 12 haftalık pilates egzersiz programı ile depresif semptomlarda \%19,8'lik bir azalma olduğunu belirtmiştir (32). Stojanovska ve ark. 2014 yılında yayımladıkları derlemede 80 çalışmaya dayanarak vardıkları sonuçta cinsiyet, yaş ve sağlık durumundan bağımsız olarak fiziksel aktivite ve klinik depresyon arasında pozitif korelasyon belirtilmiştir. Antidepresan ilaç kullanımı kesildikten sonra düzenli egzersiz yapan grubun sedanter grup ile kıyaslandığında depresyon puanları daha düşük bulunmuştur. Düzenli fiziksel aktivite yapan katılımcıların sonuçları daha iyi bir ruh hali, öz saygı, ile azalmış anksiyete ve stres sonucunda yüksek psikolojik iyilik hali durumunu göstermiştir (33). Carta ve ark 2008 yılında yaptıkları çalışmada ise bir gurup depresyon tanısı almış kadına kuvvet gerektiren çalışma yaptırarak yaşam kalitesinde istatistiksel anlamlı artış bulmuştur (34).

Çalışmamıza dahil ettiğimiz her iki gruptaki bireylerin egzersiz öncesi depresyon düzeyleri minimal seviyedeydi. 8 haftalık egzersiz eğitimi sonrasında hem stabilizasyon egzersiz grubu hem de ev egzersiz grubunun grup içi değerlendirmelerinde depresyon düzeylerinde düşüş olduğu görüldü. Ancak stabilizasyon egzersiz grubundaki değişimin anlamlı fark oluşturduğu saptandı. Bu sonuç bize postmenopozal kadınlarda depresyonun düzenli egzersiz programı ile azaltılabileceğini gösterdi.

Bu çalışmada bazı limitasyonlar bulunmaktadır. Çalışmaya dahil edilen bireylerin oluşturdukları gruplar için randomizasyon yapılamadı. Bireylerin egzersizlerin yapılacağı salona evlerinin uzaklığı nedeniyle ulaşım zorluğu yaşamaları, çalışma durumları gibi sorunlardan dolayı egzersiz gruplarını oluştururken bireylerin istekleri göz önünde tutuldu. Egzersiz eğitimi 8 hafta boyunca devam etti. Bu eğitim sonunda oluşan etkilerin uzun dönem korunup korunmadığı ile ilgili takip yapılmaması bir başka limitasyondur.

Bu çalışma ile postmenopozal dönemdeki kadınlarda hormon değişiklikleri sebebiyle yaşanan psikolojik sorunların egzersiz yöntemi kullanılarak ucuz ve etkili bir koruyucu sağlık hizmeti ile azaltılabileceği gösterildi. Bu çalışma ile postmenopozal dönemde egzersiz eğitimleri ile kadınlarda oluşabilecek semptomların azaltılması, egzersiz alışkanlığının kazandıııması ve iyilik halinin sürdürülmesi sağlanarak ülkemize kadın sağlığı açısından katkı sağladığımız düşüncesindeyiz. 


\section{Kaynaklar}

1. Nelson HD. Menopause. Lancet 2008;371:760-70. [CrossRef]

2. Grindler NM, Santoro NF. Menopause and exercise. Menopause 2015;22:1351-8. [CrossRef]

3. Melby MK, Lock M, Kaufert P. Culture and symptom reporting at menopause. Hum Reprod Update 2005;11:495-512. [CrossRef]

4. Bruce D, Rymer J. Symptoms of the menopause. Best Pract Res $\mathrm{ClOb}$ 2009;23:25-32. [CrossRef]

5. Woods NF, Mitchell ES, Tao Y, Viernes HMA, Stapleton PL, Farin FM. Polymorphisms in the estrogen synthesis and metabolism pathways and symptoms during the menopausal transition: observations from the Seattle Midlife Women's Health Study. Menopause 2006;13:90210. [CrossRef]

6. Schilling C, Gallicchio L, Miller SR, Langenberg P, Zacur H, Flaws JA. Genetic polymorphisms, hormone levels, and hot flashes in midlife women. Maturitas 2007;57:120-31. [CrossRef]

7. Thunell L, Stadberg E, Milsom I, Mattsson L-Å. A longitudinal population study of climacteric symptoms and their treatment in a random sample of Swedish women. Climacteric 2004;7:357-65. [CrossRef]

8. Smith K, Smith E. Integrating Pilates-based Core Strengthening Into Older Adult Fitness Programs: Implications for Practice. Top Geriatr Rehabil 2005;21:57-67. [CrossRef]

9. Mishra N, Mishra VN, Devanshi. Exercise beyond menopause: Dos and Don'ts. J Midlife Health 2011;2:51-6. [CrossRef]

10. Bromberger JT, Schott LL, Kravitz HM, Sowers MF, Avis NE, Gold EB, et al. Longitudinal change in reproductive hormones and depressive symptoms across the menopausal transition: results from the Study of Women's Health Across the Nation (SWAN). Arch Gen Psychiat 2010;67:598-607. [CrossRef]

11. Dugan SA, Bromberger JT, Segawa E, Avery E, Sternfeld B. Association between Physical Activity and Depressive Symptoms: Midlife Women in SWAN. Med Sci Sport Exer 2015;47:335-42. [CrossRef]

12. Hayes LD, Grace FM, Sculthorpe N, Herbert P, Ratcliffe JWT, Kilduff LP, Baker JS. The effects of a formal exercise training programme on salivary hormone concentrations and body composition in previously sedentary aging men. SpringerPlus 2013;2:18. [CrossRef]

13. Roubenoff R, Hughes VA. Sarcopenia: Current Concepts. J Gerontol A-Biol 2000;55: M716-24. [CrossRef]

14. Coyne L. Dewhurst's Textbook of Obstetrics \& Gynaecology, 7th ed. The Obstetrician \& Gynaecologist 2008;10:66. [CrossRef]

15. Thompson W, Gordon N, Pescatello L. American College of Sport Medicine. ACSM's Guidelines for exercise testing and prescription 8. painos. Philadelphia, PA. Lippincott Williams \& Wilkins, 2009; Chap. 13. pp. 23-6.

16. Chang Y. Grace under pressure: Ten years ago, 5000 people did the exercise routine called Pilates. The number now is 5 million in America alone. But what is it, exactly? Newsweek 2000;135:72-3.

17. Kharbouch SB, Sahin NH. Determination of the quality of life during menopausal stages. Istanbul Üniv FNHYO Derg 2007;15:82-90.

18. Hisli N. Depresyon envanteri'nin geçerliliği üzerine bir çalışma. Türk Psikoloji Derg 1988;6:118-22.
19. Kim M-J, Cho J, Ahn Y, Yim G, Park H-Y. Association between physical activity and menopausal symptoms in perimenopausal women. BMC Womens Health 2014;14:122. [CrossRef]

20. Mansikkamäki K, Raitanen J, Malila N, Sarkeala T, Männistö S, Fredman J, et al. Physical activity and menopause-related quality of life-A population-based cross-sectional study. Maturitas 2015;80:6974. [CrossRef]

21. Eyigor S, Karapolat H, Yesil H, Uslu R, Durmaz B. Effects of pilates exercises on functional capacity, flexibility, fatigue, depression and quality. Eur J Phys Rehab Med 2010;46:481-7.

22. Kucukcakir N, Altan L, Korkmaz N. Effects of Pilates exercises on pain, functional status and quality of life in women with postmenopausal osteoporosis. J Bodyw Mov Ther 2013;17:204-11. [CrossRef]

23. McGrath JA, O'Malley M, Hendrix TJ. Group exercise mode and health-related quality of life among healthy adults. J Adv Nurs 2011;67:491-500. [CrossRef]

24. Rodríguez-Fuentes $\mathrm{G}$, de Oliveira IM, Ogando-Berea $\mathrm{H}$, OteroGargamala MD. An observational study on the effects of Pilates on quality of life in women during menopause. Eur J Integr Med 2014;6:631-6. [CrossRef]

25. De Lorenzi DRS, Baracat EC, Saciloto B, Padilha I Jr. Fatores associados à qualidade de vida após menopausa. Rev Assoc Med Bras 2006;52:312-7. [CrossRef]

26. Daley A, MacArthur C, Stokes-Lampard H, McManus R, Wilson S, Mutrie N. Exercise participation, body mass index, and healthrelated quality of life in women of menopausal age. Brit J Gen Pract 2007;57:130-5.

27. de Souza Santos CA, Dantas EEM, Moreira MHR. Correlation of physical aptitude; functional capacity, corporal balance and quality of life (QoL) among elderly women submitted to a post-menopausal physical activities program. Arch Gerontol Geriat 2011;53:344-9. [CrossRef]

28. Villaverde-Gutiérrez C, Araujo E, Cruz F, Roa JM, Barbosa W, RuizVillaverde G. Quality of life of rural menopausal women in response to a customized exercise programme. J Adv Nurs 2006;54:11-9. [CrossRef]

29. KarlıdereT,Özşahin A. Menopozda semptom örüntüsünün anksiyete, depresyon düzeyleri ve sosyal destek ile ilişkisinin incelenmesi. Klinik Psikiyatri 2008;11:159-66.

30. Radloff LS. The CES-D scale a self-report depression scale for research in the general population. Appl Psych Meas 1977;1:385401. [CrossRef]

31. Van Praag H. Neurogenesis and exercise: past and future directions. Neuromol Med 2008;10:128-40. [CrossRef]

32. Mokhtari M, Nezakatalhossaini M, Esfarjani F. The effect of 12-week pilates exercises on depression and balance associated with falling in the elderly. Procedia Soc Behav Sci 2013;70:1714-23. [CrossRef]

33. Stojanovska L, Apostolopoulos V, Polman R, Borkoles E. To exercise, or, not to exercise, during menopause and beyond. Maturitas 2014;77:318-23. [CrossRef]

34. Carta MG, Hardoy MC, Pilu A, Sorba M, Floris A, Mannu F, et al. Improving physical quality of life with group physical activity in the adjunctive treatment of major depressive disorder. Clin Pract Epidemiol Ment Health 2008;4:1. [CrossRef] 